\title{
The effect of nitric oxide, endothelial nitric oxide synthetase, and asymmetric dimethylarginine in hemorrhoidal disease
}

\author{
(iD) Aylin Hande Gokce \\ (iD) Feridun Suat Gokce ${ }^{2}$ \\ (iD) Sinem Durmus ${ }^{3}$ \\ (iD) Ramila Hajiyeva ${ }^{4}$ \\ (D) Feyzullah Ersoz \\ (iD) Remise Gelisgen ${ }^{6}$ \\ (iD) Hafize Uzun ${ }^{6}$
}

\begin{abstract}
1. Assistant Professor. Department of General Surgery, Istanbul Atlas University Faculty of Medicine, Istanbul, Turkey. 2. Department of General Surgery, Balıklı Rum Hospital, Istanbul, Turkey. 3. Department of Medical Biochemistry, Cerrahpasa Faculty of Medicine, Istanbul University-Cerrahpasa, Istanbul, Turkey 4. Assistant Doctor. Department of Medical Biochemistry, Cerrahpasa Faculty of Medicine, Istanbul University-Cerrahpasa, Istanbul, Turkey. 5. Associate Professor. Department of General Surgery. Istanbul Training Research Hospital, Istanbul, Turkey.. 6. Professor Doctor. Department of Medical Biochemistry, Cerrahpasa Faculty of Medicine, Istanbul University-Cerrahpasa, Istanbul, Turkey
\end{abstract}

http://dx.doi.org/10.1590/1806-9282.66.8.1128

\section{SUMMARY}

AIM: The aim of this study was to examine the roles of nitric oxide (NOx), endothelial nitric oxide synthetase (eNOS), and asymmetric dimethylarginine (ADMA), which is the major endogenous inhibitor of nitric oxide synthases (NOS), in the pathophysiology of hemorrhoidal disease.

METHODS: This study included 54 patients with grades 3 and 4 internal hemorrhoidal disease and 54 patients without the disease who attended the General Surgery Clinic. NOx, eNOS, and ADMA levels were measured with the Enzyme-Linked ImmunoSorbent Assay (ELISA) method.

RESULTS: The patients had higher NO and eNOS levels and lower ADMA levels than the control subjects ( $p<0.001)$. A significant highly positive correlation was found between NO and eNOS ( $p<0.001)$. Nevertheless, there was a highly negative correlation between ADMA and NO-eNOS( $p<0.001, p<0.001)$.

CONCLUSION: This preliminary study reveals that higher NOx and eNOS activities and lower ADMA levels in the rectal mucosa are observed in patients with hemorrhoidal disease than in those with normal rectal tissue. The imbalance between endothelium-derived relaxing factors, such as NO and endogenous competitive inhibitor of NOS, ADMA, may cause hemorrhoidal disease. Our study proposes that hemorrhoids display apparent vascular dilatation and present with bleeding or swelling. ADMA is an effective NOS inhibitor and may be a promising therapeutic option for hemorrhoidal disease.

KEYWORDS: Arginine/analogs \& derivatives. Nitric oxide synthase type III. Hemorrhoids. Nitric oxide. Nitric oxide synthase.

\section{INTRODUCTION}

Hemorrhoidal tissues are normal anatomical and structural elements of the anal canal consisting of veins and muscle fibers. Hemorrhoidal disease is caused by the extension of these tissues due to several factors, including constipation, diarrhea, straining, and pregnancy. In recent studies, increasing microvascular density in hemorrhoidal tissue has been observed, suggesting that neovascularization might

DATE OF SUBMISSION: 30-May-2020

DATE OF ACCEPTANCE: 28-Jun-2020

CORRESPONDING AUTHOR: Aylin Gokce

Amatya /Istanbul - Istanbul - 34098

E-mail:ahgokce79@hotmail.com 
be another important factor of hemorrhoidal disease1.

Nitric oxide (NO) is a potent vasodilator that is synthesized from L-arginine by one of the following three nitric oxide synthases (NOS): inducible NOS (iNOS), neuronal NOS (nNOS), or endothelial NOS (eNOS). NOS was reported to increase significantly in hemorrhoids2. Although the vasodilator functions of NO are amply studied in the gastrointestinal tract, the relative contributions of NOS isoforms to hemorrhoids are unclear.

Asymmetric dimethylarginine (ADMA) is the major endogenous inhibitor of all three NOS isoforms. ADMA is produced from the proteolysis of the proteins that contain methylated arginine ${ }^{3}$. A competitive inhibitor of endogenous NOS, ADMA results in a reduction of $\mathrm{NO}$ production ${ }^{4}$. Increasing plasma ADMA levels have been reported in disease pathology in a variety of conditions that were characterized by endothelial dysfunction, including hypertension, hypercholesterolemia, renal failure, tobacco exposure, and hyperglycemia ${ }^{5,6}$. ADMA has also been indicated as an independent risk factor for coronary heart disease and endothelial dysfunction? ${ }^{7}$.

There is no adequate information in the literature regarding the relationship between human hemorrhoids and ADMA. Therefore, this study aimed to investigate the roles of NO, eNOS, and ADMA in the pathophysiology of hemorrhoidal disease.

\section{METHODS}

The protocol was approved by the local Ethics Committee of the Istanbul Education and Research Hospital (verdict number: 2019/2037) and was conducted in accordance with the Declaration of Helsinki. This study included 54 patients with grades 3 and 4 internal hemorrhoidal disease who attended the General Surgery Clinic. All subjects were of Turkish descent. They all provided informed consent for inclusion before study participation was initiated. In our clinic, the Milligan Morgan procedure was performed on patients with grades 3 and 4 internal hemorrhoids under general anesthesia. All patients with hemorrhoidal disease in the rectal mucosa underwent rectal biopsy. The area was washed with saline solution and evaluated. The control group was comprised of patients who underwent colonoscopy; those with hemorrhoidal disease, malign disease, and inflammatory bowel disease were excluded from the study. Patients who underwent rectal biopsy and whose histopathological results were normal were included in the study as the control group. The biopsies of the control group were endoscopically performed with biopsy forceps on the normal rectal mucosa close to the anus. Resected pieces were washed with saline solution. The study and control groups were referred to as Group 1 and Group 2, respectively. The samples were stored at $-80^{\circ} \mathrm{C}$ for biochemical evaluation.

\section{Preparation of tissue samples}

The Group 1 specimens were homogenized in a four-fold volume of phosphate-buffered solution (PBS, pH: 7.4) using a homogenizer (Next Advance Bullet Blender Storm 24). To remove debris, the homogenate was centrifuged at $3000 \mathrm{~g}$ for 10 minutes. The clear upper supernatant was taken, and tissue analyses (NOx, eNOS, and ADMA) were performed. All the experimental procedures were performed at $+4^{\circ} \mathrm{C}$.

Measurement of NOx, eNOS, and ADMA levels in tissue

Tissue NOx, eNOS, and ADMA levels are measured by Enzyme-Linked ImmunoSorbent Assay (ELISA) kit (SinoGeneClon Biotech Co., Ltd., HangZhou, China) as per the manufacturer's instructions. The coefficients of intra- and inter-assay variation (\% CVs) of NO, eNOS, and ADMA were less than $10 \%$.

\section{Statistical analysis}

The number of patients in the groups was calculated for NO, eNOS 3, and ADMA parameters using a testing power of $95 \%$. The minimum number of patients in the groups with and without the disease (hemorrhoidal disease) was calculated as 16 for NO and eNOS and 18 for ADMA according to Power analysis. In our study, a total of 108 patients were measured, 54 patients in each group.

Statistical analysis was performed using the Statistical Package for the Social Sciences (version 21.0). All data were first checked for normality. Then, the categorical variables were analyzed using the chi-

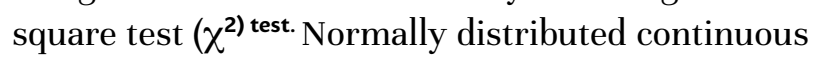
variables were presented as mean \pm standard deviation. Differences in the two groups were analyzed with the Student's $t$-test. To test the relationship between the variables, the Pearson Correlation was used. Indicative accuracy of distant markers was contrasted by analyzing the area below the receiver operating characteristic (ROC) curve, which was used to compare the diagnostic accuracy of the various markers. From the 
results of the ROC curve, odds ratios were calculated for cut-off points by multivariate analysis. Differences were considered significant when $p<0.05$.

\section{RESULTS}

The subject characteristics and circulating concentrations of biochemical parameters are found in Table 1. The patients (Group 1) had statistically significantly higher NOx and eNOS levels (for both $p<0.001$ ) and lower ADMA levels $(p<0.001)$ than the control subjects (Group 2).

We concluded that there was a significant highly positive correlation between NOx and eNOS ( $r=0.830$,

TABLE 1. DEMOGRAPHIC CHARACTERISTICS, NOX, ENOS, AND ADMA LEVELS OF GROUPS.

\begin{tabular}{l|l|l|l} 
& $\begin{array}{l}\text { Group 1 } \\
(\mathrm{n}=54)\end{array}$ & $\begin{array}{l}\text { Group 2 } \\
(\mathrm{n}=54)\end{array}$ & $\mathrm{p}$ \\
\hline Age & $37.5 \pm 7.1$ & $37.3 \pm 6.0$ & 0.849 \\
\hline Gender (Female/Male) & $29 / 25$ & $26 / 28$ & 0.568 \\
\hline NOx $(\mathrm{mmol} / \mathrm{L})$ & $176.2 \pm 18.2$ & $109.7 \pm 19.8$ & $<0.001$ \\
\hline eNOS $(\mathrm{pg} / \mathrm{mL})$ & $182.0 \pm 14.0$ & $116.4 \pm 10.3$ & $<0.001$ \\
\hline ADMA $(\mathrm{ng} / \mathrm{mL})$ & $66.4 \pm 13.8$ & $100.8 \pm 10.3$ & $<0.001$ \\
\hline
\end{tabular}

NOx: Total nitric oxide; eNOS: Endothelial nitric oxide synthetase; ADMA: Asymmetric dimethylarginine.

TABLE 2. CORRELATION OF PARAMETER DATA IN GROUP 1

\begin{tabular}{l|l|l|l|l} 
& & $\begin{array}{l}\text { eNOS } \\
(\mathrm{pg} / \mathrm{mL})\end{array}$ & $\begin{array}{l}\text { ADMA (ng/ } \\
\mathrm{mL})\end{array}$ & Age \\
\hline NOx (mmol/L) & $r$ & $0.830^{* *}$ & -0.676 & -0.069 \\
& $p$ & 0.000 & 0.000 & 0.621 \\
\hline eNOS (pg/mL) & $r$ & - & -0.684 & -0.127 \\
& $p$ & & 0.000 & 0.360 \\
\hline ADMA (ng/mL) & $r$ & -0.684 & - & -0.119 \\
& $p$ & 0.000 & - & 0.390 \\
\hline
\end{tabular}

NOx: Total nitric oxide; eNOS: Endothelial nitric oxide synthetase; ADMA: Asymmetric dimethylarginine. Spearman correlation analysis was used. ${ }^{*} p<0.05 ;{ }^{* * *} p<0.01$; ${ }^{* \star *} p<0.001$ $p<0.001$ ) (Table 2). Furthermore, we assessed that ADMA is highly negatively correlated with NOx $(r=-0.676, p<0.001)$ and eNOS $(r=-0.684, p<0.001)$ (Table 2). We noted that the eNOS levels had an excellent diagnostic performance in the differentiation between the groups $[(\mathrm{AUC})=1.000,95 \%$ confidence interval (CI): 1.00-1.00)] $p<0.001$, with both 100\% sensitivity and specificity for a cut-off point at 140.65 $\mathrm{pg} / \mathrm{mL}$.

In addition, the AUC of NOx was 0.959 (95\% CI: $0.909-1.00$ ) with $100 \%$ specificity and $94.4 \%$ sensitivity for a cut-off point at $125.60 \mathrm{mmol} / \mathrm{L}$ (Table 3). Multivariate analysis showed that if eNOS is greater than $140.65 \mathrm{pg} / \mathrm{mL}$, the disease risk increases 2010-fold $(p=0.0002)$, and if NOx is greater than $125.60 \mathrm{mmol} / \mathrm{L}$, the disease risk increases 185 -fold $(p=0.0006)$.

\section{DISCUSSION}

This preliminary study revealed that higher NOx and eNOS activities and lower ADMA levels in the rectal mucosa were observed in patients with hemorrhoidal disease than in those with normal rectal tissue. An imbalance between a endothelium-derived relaxing factor, such as NO, and the endogenous competitive inhibitor of NOS, ADMA, may cause hemorrhoidal disease. This study found that hemorrhoids display apparent vascular dilatation and manifest with bleeding or swelling. ADMA is an effective NOS inhibitor and it may be a promising therapeutic option for hemorrhoidal disease.

Hemorrhoidal disease is more common in people over 30 years old8. In this study, the mean age of the subjects was 37.5 years in Group 1 and 37.3 years in Group 2, consistent with what is found in the literature. There was no remarkable difference in age between Groups 1 and 2. There was also no remarkable difference in the incidence rates of hemorrhoidal disease in men and women8. the sex distribution of the patients included in this study was approximately

TABLE 3. CUT-OFF POINTS ACCORDING TO ROC CURVE, SENSITIVITY, SPECIFICITY, AND AUC FOR NITRIC OXIDE (NOX) AND ENDOTHELIAL NITRIC OXIDE SYNTHETASE (ENOS).

\begin{tabular}{l|l|l|l|l|l|l|l} 
& & \multicolumn{3}{|c|}{$\begin{array}{l}\text { Asymptotic 95\% Confidence } \\
\text { Interval }\end{array}$} & & \\
\hline Variable(s) & AUC & P & Lower Threshold & Upper Threshold & Cut-off points & Sensivity & Specificity \\
\hline NOx $(\mathrm{mmol} / \mathrm{L})$ & 0.959 & 0.000 & 0.909 & 1.000 & 125.60 & $\% 94.4$ & $\% 100$ \\
\hline eNOS $(\mathrm{pg} / \mathrm{mL})$ & 1.000 & 0.000 & 1.000 & 1.000 & 140.65 & $\% 100$ \\
\hline
\end{tabular}

NOx: Total nitric oxide; eNOS: Endothelial nitric oxide synthetase; AUC: Area under the curve. 
the same, consistent also with the literature. There was no remarkable difference in sex between Groups 1 and 2 .

NO exerts physiological functions in the nervous and immune systems, contributing to behavior regulation, defense mechanisms against infectious disease, tumors, and gastrointestinal motility9. In this study, the amount of NO in Group 1 was remarkably higher than that in Group 2. Hemorrhoidal disease occurs due to the dilatation of hemorrhoid lumps that normally exist in the rectal area10. We consider that NO has an important role in the etiology of hemorrhoids, since it is released to lower pressure against causes that increase the pressure, like coughing, straining, and pregnancy. It supports our opinion that the NO level in rectal tissue excised from the patients with hemorrhoidal disease was higher than that of the control group.

Indeed, eNOS has received even more attention than NO due to its instability and the regulatory mechanisms of eNOS on NO production11. In hemorrhoids, NOS, an enzyme that synthesizes nitric oxide from L-arginine, was reported to increase remarkably12. García-Martín et al.13 reported that the eNOS level was higher in people with migraines and had a history of migraines in their families and that eNOS inhibitors could be used in the treatment. There are publications revealing that a low level of eNOS is related to coronary artery disease 14,15 , essential hypertension16, and multiple sclerosis17. In our study, the eNOS level of Group 1 was remarkably higher than that of Group 2. It supports the opinion that eNOS and NOx have an effect on the occurrence of hemorrhoidal disease.

Lohsiriwat et al.2 observed NOS protein expression in tissue extracts of hemorrhoid and rectal tissue by Western blot analysis. Furthermore, they compared the expression levels to those of human microvascular endothelial cells. They also studied the distribution of all NOS isoforms in the tissue sections using immunohistochemistry. They provided further evidence that hemorrhoids have a higher protein expression of all NOS isoforms than the rectal tissue. There are considerably higher levels of nNOS and eNOS in the rectal tissue of patients with hemorrhoidal disease than in those with normal rectal tissue, suggesting that blood vessels in hemorrhoids are exposed to higher NO concentrations than those of normal rectal tissue. It appears that the bleeding or swelling caused by vascular dilatation might play an important role in hemorrhoidal symptoms and could be a potential target for medical treatment. NOS reduction, by applying NOS inhibitors, could likely improve these symptoms. There are publications revealing that ADMA, released as an endogenic and natural inhibitor of eNOS, increases hypercholesterolemia, coronary artery disease, and diabetes mellitus18. Even in a healthy population, high levels of circulating ADMA may be associated with higher rates of all-cause death19. Nevertheless, there is no adequate information in the literature regarding the relationship between human hemorrhoids and ADMA. Ragina et al.20 reported a clear and remarkable rise in systemic ADMA levels after laparoscopic colorectal surgery, even in the absence of surgical complications. The ADMA level of Group 1 was remarkably lower than that of Group 2. ADMA was very strongly negatively correlated with NO and eNOS. It is considered that vasodilatation of the hemorrhoidal masses is caused by the increase in ADMA release against increased NO and eNOS. Thus, NO release inhibition or insufficient ADMA levels can be one of the underlying causes.

Vasodilation in hemorrhoidal veins develops due to causes such as constipation, pregnancy, and coughing, which increase intraabdominal pressure. Therefore, the usability of NOS inhibitors in hemorrhoidal disease against increasing vasodilator NO and eNOS should be further studied.

We firmly believe that if our study had been conducted with a larger patient series, the results would have provided more guidance. The fact that ADMA, an endogenous NOS inhibitor, is associated with hemorrhoidal disease and other diseases has limited our ability to compare our study with others.

This study shows more detailed evidence that the rectal tissue of patients with hemorrhoidal disease has intense NOx and eNOS activities and lower ADMA levels than the normal rectal tissue, indicating that hemorrhoids are associated with noticeable vascular dilatation, high blood perfusion, tissue swelling, and bleeding tendency. If known changes in the blood flow in hemorrhoids can be explained by changes in NOx, eNOS, and ADMA levels described herein, a decrease in eNOS could potentially improve the hemorrhoid symptoms.

ADMA is an effective NOS inhibitor that may be a promising therapeutic option for hemorrhoidal disease. Further investigations are necessary to elucidate this hypothesis. 


\section{Conflict of interest}

The authors declare that there is no conflict of interest related to the publication of this manuscript. No competing financial interests exist. The authors received no specific funding for this article.

No competing financial interests exist. This research didn't receive grants from any funding agency in the public, commercial, or not-for-profit sectors. There are no conflicts of interest. Ethics approval for this study was obtained from the Ethics Committee (Verdict number: 2019/2037).

\section{Author's Contribution}

Planning: Aylin Hande Gokce, Feridun Suat Gokce,
Hafize Uzun, Sinem Durmus, Feyzullah Ersoz.

Data collection: Aylin Hande Gokce, Feridun Suat Gokce, Hafize Uzun, Ramila Hajiyeva, Remise Gelişgen.

Data entry: Aylin Hande Gokce, Feridun Suat Gokce, Ramila Hajiyeva, Feyzullah Ersoz.

Data analysis: Aylin Hande Gokce, Feridun Suat Gokce, Hafize Uzun, Ramila Hajiyeva, Sinem Durmus, Remise Gelisgen.

Article writing: Aylin Hande Gokce, Feridun Suat Gokce, Hafize Uzun, Sinem Durmus.

Manuscript analysis and interpretation: Aylin Hande Gokce, Feridun Suat Gokce, Ramila Hajiyeva, Feyzullah Ersoz, Remise Gelisgen.

\section{RESUMO}

OBJETIVO: O objetivo deste estudo foi examinar os papéis do óxido nítrico (NOx), do óxido nítrico sintetase endotelial (eNOS) e da dimetilarginina assimétrica (ADMA), que é o principal inibidor endógeno das óxido nítrico sintase (NOS) na fisiopatologia da doença hemorróida.

MÉTODOS: Este estudo incluiu 54 pacientes com doença hemorróida interna de grau 3 e 4 e 54 pacientes sem a doença que se inscreveram na Clínica Geral de Cirurgia. Os níveis de NOx, eNOS e ADMA foram medidos com o método de Ensaio Imuno absorvente ligado a enzima (ELISA).

RESULTADOS: Os pacientes têm níveis mais altos de NO e eNOS e níveis mais baixos de ADMA do que os indivíduos controle ( $p<0,001)$. Uma correlação altamente positiva significativa foi encontrada entre o NO-eNOS ( $p<0,001)$. No entanto, houve uma correlação negativa muito séria entre ADMA e NO-eNOS ( $p<0,001, p<0,001)$.

CONCLUSÃO: Este estudo preliminar revela que os pacientes com doença hemorróida têm atividades mais altas de NOx e eNOS e níveis mais baixos de ADMA na mucosa retal do que os pacientes com tecido retal normal. Desequilíbrio entre o fator relaxante derivado do endotélio, como; O NO e o inibidor competitivo endógeno da NOS, ADMA, podem causar doenças hemorróidas. Nosso estudo propõe que as hemorróidas exibam aparente dilatação vascular e apresentam sangramento ou inchaço, a ADMA é um inibidor eficaz da NOS e pode ser uma opção terapêutica promissora para a doença hemorróida.

PALAVRAS-CHAVE: Arginina/análogos \& derivados. Óxido nítrico sintase tipo III. Hemorroidas. Óxido nítrico. Óxido nítrico sintase.

\section{REFERENCES}

1. Lohsiriwat V. Hemorrhoids: from basic pathophysiology to clinical management. World J Gastroenterol. 2012;18(17):2009-17.

2. Lohsiriwat V, Wilson VG, Scholefield JH, Dashwood MR. Regional distribution of nitric oxide synthase in human anorectal tissue: a pilot study on the potential role for nitric oxide in haemorrhoids. Curr Vasc Pharmacol. 2020;18(1):43-9.

3. Tain $\mathrm{YL}, \mathrm{Hsu} \mathrm{CN}$. Toxic dimethylarginines: asymmetric dimethylarginine (ADMA) and symmetric dimethylarginine (SDMA). Toxins (Basel). 2017;9(3):92.

4. Shin S, Thapa SK, Fung HL. Cellular interactions between L-arginine and asymmetric dimethylarginine: transport and metabolism. PLoS One. 2017;12(5):e0178710

5. Cooke JP. Asymmetric dimethylarginine: the uber marker? Circulation 2004;109(15):1813-8

6. Vallance P, Leiper J. Cardiovascular biology of the asymmetric dimethylarginine:dimethylarginine dimethylaminohydrolase pathway. Arterioscler Thromb Vasc Biol. 2004;24(6):1023-30.
7. Franceschelli S, Ferrone A, Pesce M, Riccioni G, Speranza L. Biological functional relevance of asymmetric dimethylarginine (ADMA) in cardiovascular disease. Int J Mol Sci. 2013;14(12):24412-21.

8. Pigot F, Siproudhis L, Allaert FA. Risk factors associated with hemorrhoidal symptoms in specialized consultation. Gastroenterol Clin Biol. 2005;29(12):1270-4

9. Zhao Y, Vanhoutte PM, Leung SW. Vascular nitric oxide: beyond eNOS. Pharmacol Sci. 2015;129(2):83-94.

10. Sanchez C, Chinn BT. Hemorrhoids. Clin Colon Rectal Surg. 2011;24(1):5-13.

11. Zhu J, Song W, Li L, Fan X. Endothelial nitric oxide synthase: a potential therapeutic target for cerebrovascular diseases. Mol Brain. 2016;9:30.

12. Han W, Wang ZI, Zhao B, Yang XQ, Wang D, Wang IP, et al. Pathologic change of elastic fibers with difference of microvessel density and expression of angiogenesis-related proteins in internal hemorrhoid tissues. Zhonghua Wei Chang Wai Ke Za Zhi. 2005;8(1):56-9. 
13. García-Martín E, Navarro-Muñoz S, Rodriguez C, Serrador M, Alonso-Navarro $\mathrm{H}$, Calleia $M$, et al. Association between endothelial nitric oxide synthase (NOS3) rs2070744 and the risk for migraine. Pharmacogenomics ). 2019;20(3):426-32

14. Dong |, Ping $Y$, Wang $Y$, Zang $Y$. The roles of endothelial nitric oxide synthase gene polymorphisms in diabetes mellitus and its associated vascular complications: a systematic review and meta-analysis. Endocrine. 2018;62(2):412-22.

15. Li X, Lin Y, Zhang R. Associations between endothelial nitric oxide synthase gene polymorphisms and the risk of coronary artery disease: a systematic review and meta-analysis of 132 case-control studies. Eur | Prev Cardiol. 2019;26(2):160-70

16. Gamil S, Erdmann I, Abdalrahman IB, Mohamed AO. Association of NOS3 gene polymorphisms with essential hypertension in Sudanese patients: a case control study. BMC Med Genet. 2017;18(1):128.
17. Heidari MM, Khatami M, Tahamtan Y. Molecular analysis of rs2070744 and rs1799983 polymorphisms of NOS3 gene in Iranian patients with multiple sclerosis. Basic Clin Neurosci. 2017;8(4):279-84.

18. Chen CH, Zhao JF, Hsu CP, Kou YR, Lu TM, Lee TS. The detrimental effect of asymmetric dimethylarginine on cholesterol efflux of macrophage foam cells: role of the NOX/ROS signaling. Free Radic Biol Med. 2019;143:354-65.

19. Maas R, Schulze F, Baumert J, Löwel H, Hamraz K, Schwedhelm E, et al. Asymmetric dimethylarginine, smoking, and risk of coronary heart disease in apparently healthy men: prospective analysis from the population-based monitoring of trends and determinants in cardiovascular disease/Kooperative Gesundheitsforschung in der region Augsburg study and experimental data. Clin Chem. 2007;53(4):693-701.

20. Ragina N, Davis G, Doorly M, Cologne K, Senagore AJ. Arginine/asymmetric dimethylarginine ratio in colorectal surgery. J Clin Med Res. 2017:9(7):555-9. 